\title{
STATE TRADING IN THE SINO-SOVIET BLOC
}

\author{
Raymond F. Mikeseliz and Donald A. Weizs $\dagger$
}

\section{INTRODUCTION}

Monopoly of foreign trade by the state is inherent in the economic and political system of communist countries. Virtually all foreign trade of the Sino-Soviet bloc is conducted by agencies of the state. In r957, total exports of bloc countries accounted for ten per cent of total world exports, including trade between members of the bloc, and three per cent of world exports, excluding intrabloc trade. ${ }^{1}$ (See table one.) While bloc trade with the free world is a comparatively minor proportion of total world trade, it accounts for a large portion, probably well over half, of the world's trade currently subject to state trading. Much of the trade of the Sino-Soviet bloc with the rest of the world is conducted with private frrms on the free-world side, and bloc trading policies and techniques, including credit arrangements, have greatly influenced the trading practices of their trading partners.

\section{TABLE I}

World Exports by Origin and Destination, 1957

Billions of Current Dollars, f.o.B.

\begin{tabular}{|c|c|c|c|c|c|c|}
\hline \multirow[b]{2}{*}{ Exporting Area } & \multicolumn{6}{|c|}{ AREa of Destination } \\
\hline & $\begin{array}{l}\text { Total Free } \\
\text { World }\end{array}$ & $\begin{array}{l}\text { Soviet } \\
\text { Union }\end{array}$ & $\begin{array}{c}\text { East } \\
\text { Europe }\end{array}$ & $\underset{\text { China }}{\text { Communist }}$ & $\begin{array}{c}\text { Total Sino- } \\
\text { Soviet } \\
\text { Bloc }^{\mathrm{a}}\end{array}$ & World \\
\hline 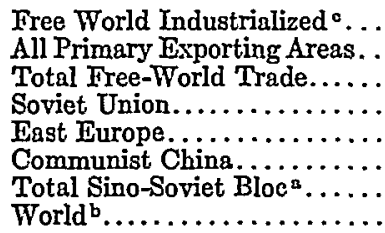 & $\begin{array}{l}65.3 \\
28.1 \\
93.4 \\
.96 \\
1.19 \\
.60 \\
2.75 \\
96.2\end{array}$ & $\begin{array}{l}.64 \\
.35 \\
.99 \\
1.98 \\
.74 \\
2.94 \\
3.9\end{array}$ & $\begin{array}{l}1.01^{\mathrm{d}} \\
.34 \\
1.35 \\
2.55 \\
1.41 \\
.26 \\
4.21 \\
5.5\end{array}$ & $\begin{array}{l}.30 \\
.23 \\
.53 \\
.54 \\
.30 \\
1.34 \\
1.9\end{array}$ & $\begin{array}{r}1.95 \\
.92 \\
2.87 \\
3.23 \\
3.83 \\
1.53 \\
8.49 \\
11.4\end{array}$ & $\begin{array}{r}70.2 \\
29.6 \\
99.8 \\
4.4 \\
55.0 \\
2.1 \\
11.5 \\
111.3\end{array}$ \\
\hline
\end{tabular}

n Ineluding trade with Afongolia, North Vietnam, and North Korea.

b World totals include special categories, unallocated exports, and some statistical discrepancy due to the utilization of various sources of dats.

- Includes trade of West Europe, United States, and Japan.

d Excluding trade between East and West Germany.

Sounce: Economic Commission for Europe, Economic Bulletin for Europe, Aug. 1958, table 3, p. 38.

* B.A. 1935, M.A. 1935, Ph.D. 1939, Ohio State University. W. E. Miner Professor of Economics and Acting Director of the Institute of International Studies and Overseas Administration, University of Oregon. Author, Foreign Exchange in the Postwar World (I954), U.S. Economic Policy and INternational. Relations (1952); co-author [with Jack N. Behrman], Financing Free Wordd Trade. WITH THE SiNo-Soviet BLoc (1958).

+ B.A. 1953, DePauw University; Certificate of Graduate Studies 1957, Graduate Institute of International Studies, Geneva, Switzerland; M.A. 1958, University of Virginia. Woodrow Wilson Fellow in Economics, University of Oregon.

${ }^{1}$ Free-world exports to the Sino-Soviet bloc in 1957 also represented about $3 \%$ of total world exports, excluding intrabloc trade. 
The purpose of this article is to review the organization, and the trade and payments practices and policies of the Sino-Soviet-bloc countries in trade among themselves and with the rest of the world. In the course of this review, we shall be especially concerned with three questions:

r. What has been the influence of bloc trading practices on state trading in the free world?

2. What are the implications of bloc trading practices and policies for free-world trade with bloc countries?

3. What are the areas, if any, in which international cooperation would be both fruitful and feasible?

\section{I}

Organization and Conduct of Trade by Bloc Countries

In Sino-Soviet-bloc countries, foreign trade is under the control of the central government, and foreign trade policies and activities are directed toward achieving the economic and political objectives of the state. In the case of the European satellite countries, the central governments' own objectives may at times be modified by pressure from Moscow or by decisions of the Council of Economic Mutual Assistance (CEMA). With few exceptions, actual foreign trade transactions are handled by foreign trade corporations which act as intermediaries between the producing, consuming, or distributing agencies on the one hand, and foreign buyers and sellers on the other. The foreign trade corporations are under the supervision of the ministry of foreign trade. The ministry is responsible for such operations as drafting plans for foreign trade and supervising their implementation, issuing permits for exports and imports, drafting trade agreements, developing economic ties with other states, and guiding the work of transportation agencies in foreign trade. ${ }^{2}$ The ministry of foreign trade also supervises trade negotiations, and trade delegations are almost invariably headed by members of the ministry of foreign trade.

Each bloc country has a number of foreign trade corporations, each corporation having responsibility for conducting the country's trade in certain types of products. As of December 1955, the Soviet Union had twenty-three foreign trade corporations; Communist China, eighteen; Czechoslovakia, twenty-five; Hungary, twenty-four; Poland, twenty-six; Rumania, fourteen; and Bulgaria, twelve. For example, in the Soviet Union, the Soiuznefteksport exports petroleum and petroleum products; the Prodintorg exports and imports caviar, fish and meat products, canned fruits, fats, oils, vodka, wine, poultry, horses, pedigreed cattle, and wild animals; the Machinoeksport handles exports of electrical, chemical, transport, and light industrial equipment; and the Eksportlen handles exports and imports of textiles and textile raw materials. ${ }^{3}$

2 See A. M. Smirnov \& N. N. Luibimov (Eds.), Vneshniaia Torgovlia SSSR [Foreign Trude op THE U.S.S.R.] 77 (1954).

${ }^{3}$ See London Chamber of Commerce, Anglo-Soviet Trade app. 5 (1957). 
It is significant that in bloc countries, state enterprises which actually produce goods for export or employ imports such as machinery and raw materials in their operations are not ordinarily permitted to engage in foreign trade. On the other hand, state enterprises have been given a certain amount of freedom in their domestic operations-hiring labor, buying materials and equipment, etc. Although prices are controlled, operations must be conducted within the framework of costs and selling prices. But, as we shall see, the prices involved in foreign trade are not related to the internal price structure; the foreign trade corporations may sell at prices substantially lower or higher than internal prices and buy at prices which depart markedly from the internal levels.

In contrast with the situation in the Sino-Soviet bloc, Yugoslavia has turned over a substantial portion of her foreign trade to state-owned producing enterprises, some five hundred of which are licensed to buy and sell directly in foreign markets. ${ }^{4}$ While a system of multiple rates together with other controls in Yugoslavia prevent a full integration of internal with world prices, Yugoslav firms are permitted to carry on foreign transactions in a manner more nearly in accord with commercial principles.

Although it is clear that foreign trade in the Sino-Soviet-bloc countries is governed by, and is an integral part of, the over-all national economic plan, it is not always clear just what role external trade plays in the planning. During the early postwar years, trade was viewed principally as a means of meeting specific domestic deficiencies." Since I95I, some degree of coordination of long-range national trade and production plans has been achieved within the bloc through the CEMA. This has been accompanied by a sharp expansion in intrabloc trade, both absolutely and in relation to extrabloc trade. However, there is little evidence of long-range planning and resource allocation directed toward extrabloc trade based on relative cost or comparative advantage. There is a desire to expand trade with the less-developed areas, and undoubtedly Sino-Soviet-bloc resource allocation takes this into account. The exchange of bloc industrial products, including capital goods, against raw materials from the less-developed countries fits into the industrialization programs of bloc countries and their emphasis on heavy industry.

From the standpoint of optimum resource allocation and maximization of the social product, socialist countries should seek to import commodities for which the relative cost of home production is high and to export commodities in the production of which they have a relative cost advantage. In other words, they should seek to acquire additional goods from abroad so long as the additional cost of acquiring an additional unit by producing exports is less than the additional cost of producing the imported items directly. However, inherent in the politicoeconomic systems of bloc countries are serious obstacles to this type of trade planning. For one thing, their in-

\footnotetext{
- See Nicolas Spulber, The Economics of Communist Eastern Europe is8 (i957).

- See Spulber \& Gehrels, The Operation of Trade within the Soviet Bloc, 40 REv. Econ. \& STAT. 140, 143 (1958).
} 
ternal accounting systems do not lend themselves readily to the calculation of relative economic costs. Second, for reasons which will be indicated below, their trade is tied to a bilateral rather than a multilateral pattern. This practice considerably restricts the scope for over-all trade planning in accordance with the maximizing principle indicated above. Finally, both their trade and the broad direction of their economic development are dictated in considerable measure by ideological, political, and military factors.

These same reasons help to explain why the foreign trade of bloc countries probably will continue to be subject to centralized planning and control. While there is some evidence of decentralization in industry and agriculture within the Soviet Union and other European bloc countries, a substantial movement toward freedom of foreign trade by individual state enterprises seems unlikely, even within the Soviet orbit. ${ }^{6}$

\section{II}

\section{INTRABLOC Trade}

Before World War II, trade among the countries of East Europe (including the Soviet Union) represented only ten per cent of the total trade of the region, and Soviet participation in this trade was minor. In I957, the exports of the Sino-Sovietbloc countries to one another constituted about seventy-five per cent of their total exports. Intrabloc trade is conducted primarily by means of a network of trade and payments agreements. Basic agreements covering types of commodities to be traded and other conditions of trade are normally drawn up for five-year periods, but the specific quantities of goods to be exchanged are negotiated on an annual basis. Trade agreements stipulate balanced trade, unless triangular deals are arranged or there are clearing balances from previous years to be settled. Payment for individual transactions is made by crediting or debiting clearing accounts in the state banks. These accounts are denominated in rubles, and all prices in intrabloc trade are quoted in rubles.

Ruble prices charged for commodities entering into foreign trade may be substantially above or below internal prices for the same commodities. ${ }^{7}$ There are

\footnotetext{
'There are conflicting and incomplete reports on the extent of decentralization in bloc countries and its significance for foreign trade. It was reported that "The negotiation and conclusion of contracts is being handed over increasingly to the enterprises directly concerned. The decentralization of trade seems to have made most headway in East Germany and Hungary. In the former country, certain export industries are now allowed to retain a share of their foreign exchange earnings to be used for imports of essential materials. Recently, both Hungary and East Germany have given certain large enterprises, mostly in the engineering industry, the right to export without the participation of the state trading agencies." 8 ECON. Bull. FOR Europe $6 \mathrm{I}$ (1956). On the other hand, in the course of a mecting of jurists on peaceful cooperation held in Rome in February 1958, the question was raised as to whether the current movement toward decentralization of planning, administration, and operation of industry in East Europe might lead to increased multilateralism in foreign trade. The East European participant replied that "there has been no decentralization in foreign trade." Harold J. Berman, MEetino of Jurists on Peaceful Cooperation, Final Report 5 (Doc. No. UNESCO/SS/Coop/Inter/I) (1958).

' See Spulber \& Gehrels, The Operation of Trade within the Soviet Bloc, Rev. Econ. \& STAT. I40, 143, 145 (1958).
} 
several reasons for this. First, the foreign trade corporations do not need to be guided by profit-and-loss calculations on individual transactions. If they sell below cost to a foreign country, the corporations can make an equivalent profit on other exports or on sales of imports to the domestic economy. Moreover, the very nature of the bilateral bargaining process makes their offer prices for exports dependent upon the prices asked by the partner country for the goods they are seeking to import. Of importance are the barter terms of trade, and not the price tags attached to the goods being exported. This is true because the relative purchasing power of the various bloc currencies in terms of domestic price levels is not reflected in their official exchange rates. ${ }^{8}$ Finally, the offer curves of the foreign trade corporations are often based on the more urgent requirements of the economy as a whole in relation to commodities which can be spared more readily; they need not conform to the profit-and-loss calculations of individual firms.

To the extent that Sino-Soviet-bloc pricing is based on unit costs, it is significant to note that communist ideology, with its emphasis on labor value, has led to the omission in cost accounting of certain important economic costs. These include the omission of interest on capital and of economic rent of scarce resources. ${ }^{9}$ One can imagine the effect on the American price system of establishing prices for petroleum or copper or corn or fashionable Fifth Avenue dresses on the basis of the labor costs involved, plus a variable profit mark-up. When a percentage mark-up is charged, it only enhances rather than corrects the price distortions as compared with price patterns in a free-enterprise economy.

The failure of accounting costs to reflect economic costs, the frequent absence of any relation between unit costs and prices in foreign trade transactions, the traditional Sino-Soviet propensity for self-sufficiency, and the tendency to base investment programs and resource allocation more on political and military objectives than on the principles of comparative advantage suggest that Sino-Soviet-bloc trade planning is inefficient. From the standpoint of maximizing the material welfare of its citizens, we might regard the entire Sino-Soviet-bloc system as highly inefficient. On the other hand, the system has given a higher priority to certain other objectives, and these are being pursued with alarming effectiveness. Perhaps many aspects of the bloc's trading policies must be viewed in the same light.

All this is not to say that comparative advantage plays an insignificant role in bloc trade planning. Within the Sino-Soviet bloc, there has been long-range trade planning. The Five-Year Plans for the $195^{6-60}$ period, which were coordinated by the CEMA, reveal increasing specialization for intrabloc trade. However, individual bloc countries continue to formulate their own economic and trade plans, and any specialization among bloc countries comes more as a result of negotiation "than as a result of

${ }^{8}$ See Ames, International Trade Without Markets-the Soviet Bloc Case, 44 AM. Econ. REv. 794 (I954).

See Spulber \& Gehrels, The Operation of Trade within the Soviet Bloc, Rev. Econ. \& Stat. I40, I43, 146-47 (I958). 
deliberate assessment of the comparative costs of different production and trade patterns."10

\section{III}

\section{East-West Trade and Payments}

Much that has been said regarding intrabloc trade applies equally to planning and prices in the Sino-Soviet-bloc trade with the rest of the world. There are a number of important modifications, however. In trade with West Europe, North America, and a number of other countries where markets are relatively free and trade is largely in private hands, prices of commodities traded with the bloc must be more or less in line with world prices. Also, trade with a number of Western countries either is not conducted under bilateral trade agreements or the agreements are far less rigid than is the case with intrabloc agreements. Even where formal trade agreements exist, payment is sometimes made in transferable currencies, rather than by crediting a clearing account.

About seventy per cent of the Sino-Soviet-bloc trade with the free world is conducted under bilateral trade and payments agreements. Most of the agreements are negotiated by governments, but in some cases, Western semiofficial bodies, such as chambers of commerce, act as the negotiating agents. This is true, for example, of a number of the agreements negotiated with East Germany by countries which do not accord diplomatic recognition to that country.

The typical trade agreement contains lists of commodities and corresponding quotas, which are negotiated each year; the basic trade and payments agreements, however, may cover a longer period of time, sometimes up to five years. The quota lists specify quantities or values of commodities to be traded. The quotas tend to be permissive rather than contractual. Where trade is in private hands, the Western country agrees to issue licenses equal in value to the quotas if they are asked for by domestic exporters and importers; there is no guarantee that the quotas will be utilized. Where Western trade in certain commodities is subject to state trading, state enterprises will endeavor to export or import the quantities indicated by the quotas. The Eastern country also agrees to import and export the agreed amounts. However, since prices are usually not set forth in the trade agreements, but are subject to negotiation by importers and exporters, actual fulfillment of quotas depends upon reaching a satisfactory agreement on price and quality for each of the commodities to be traded. This qualification enables Sino-Soviet-bloc countries to buy and sell as they desire, since there may easily be differences of opinion, feigned or real, as to what constitute satisfactory price and quality. The trade targets usually provide for bilaterally balanced trade, unless debt settlements are involved.

Quotas are often not fulfilled. For example, in 1958, Finland's trade agreement with the Soviet Union called for imports of automobiles from the Soviet Union to the value of $\$ 60,000,000$; instead, imports valued at only $\$ 20,000,000$ are expected to

\footnotetext{
${ }^{10}$ Economic Commission for Europe, Economic Survey of Europe in 1957, at 29 (1958).
} 
be reached.11 A study of the operation of 238 selected East-West trade agreements indicated that the actual trade balance differed from the target balance set forth in the trade agreements by more than $\$ 500,000$ in seventy-nine per cent of the cases. $^{12}$

\section{A. Payments Agreements}

Payments arrangements for the financing of trade between Sino-Soviet-bloc countries and the free world may be classified as follows: (a) those employing clearing accounts; (b) those calling for payment in transferable currencies; and (c) those providing for barter and private compensation agreements. ${ }^{13}$ The clearing account has been the one most commonly employed. In this type of agreement, the central bank or official clearing office of one or both countries maintains the account. Imports and other transactions giving rise to payments to the partner country are recorded as debits on the paying country's account, and the account is credited when payments are received for exports. The basic features of the clearing-account agreements are as follows:

I. The unit of account has generally been the currency of the free world country in the case of West European countries and the dollar or sterling for nonEuropean countries.

2. The types of transactions financed through the accounts are usually specified; sometimes only merchandise trade is included, while in other cases, invisible items such as shipping and insurance are included.

3. Credit provisions in the form of a swing credit are usually specified, because it would be virtually impossible for trade to be balanced at all times. The swing credit sets a limit on the amount of deficit a country may ordinarily run in the clearing account. It tends to range from five to twenty per cent of of the amount of trade in each direction which is anticipated in the trade agreement.

4. The methods for the settlement of balances which exceed the stipulated swing credit or which are outstanding at the end of the agreement period are generally included in the payments agreement. The most common provision for settlement calls for commodity deliveries to redress the balance. Efforts to restore balance by deliveries are often reflected in quota lists of subsequent trade agreements. In some cases, settlement of excessive balances is to be made by convertible currencies or by methods to be determined by negotiation. However, most agreements stipulate that deliveries of commodities for settling the balance are to be made within a specified time period, usually six months. If balance is not achieved by that time, settlement must be made in gold, dollars, or other currency acceptable to the creditor.

\footnotetext{
${ }^{11}$ See International Financial News Survey, Oct. 24, I958, p. 135 .

10 Raymond F. Mikesell \& Jack N. Behrman, Financing Free World Trade with the SinoSOVIET Bloc 85-86 (1958).

18 For a detailed discussion, see id. at 30-53.
} 
While trade agreements retain their prominence as the instrument for conducting East-West trade, there are indications that free world countries are moving away from clearing-account agreements with bloc countries in favor of financing with transferable currencies. During $1956-57$, West Germany introduced limited convertible Deutsche marks, the so-called Beko-marks, as the means of payment in trade with several East European countries. Beko-marks are transferable throughout a wide area, including the European Payments Union (EPU) countries (except Turkey), Argentina, Brazil, Egypt, Finland, Iran, Japan, Paraguay, Spain, Uruguay, Yugoslavia, Bulgaria, Czechoslovakia, Hungary, Poland, and Rumania. All bloc trade with the United Kingdom is conducted in transferable sterling. Italy has introduced a multilateral lire, transferable throughout the EPU area and certain other nondollar countries, into its trade with East Germany and the Soviet Union. The agreements of India and Pakistan call for payments to be made in sterling or rupees, and Indonesia finances her trade with all block countries except Communist China with sterling.

\section{B. Pricing Policies}

The prices of bloc exports to free-world countries depend in considerable measure on the type of negotiation involved and how anxious the bloc country is to sell its product, either for economic or political reasons. In recent Soviet sales of aluminum, tin, and other raw materials in free Western markets, goods were priced sufficiently below current market levels to dispose of the amount the Soviet Union was seeking to sell. Likewise, Communist China has greatly expanded her exports of textiles in South Asia-largely at the expense of Indian textile exports-by offering lower prices and more favorable credit terms. ${ }^{14}$ On the other hand, bloc countries have been accused of price-gouging in sales of manufactures under bilateral trade agreements with Burma and Indonesia. ${ }^{15}$ When bloc countries run up deficits in clearing accounts by importing at a faster rate than they deliver exports, they are in a position to force unfavorable terms on their trading partners, since the latter are anxious to receive payment for the credits they have extended.

There are numerous examples of discrimination in bloc pricing practices. To some countries, especially favorable treatment may be given, perhaps for political reasons; in other cases, prices are at world-market levels; while in others, the exercise of bargaining power under the bilateral agreement enables the bloc country to sell at substantially higher than world prices. In 1955, the dollar price per ton of Hungary's exports of crude aluminum varied as follows: $\$ 39 \mathrm{r}$ per ton to Poland; $\$ 900$ per ton to Communist China; and $\$ 522$ per ton to Switzerland. The export price of Bulgarian nitrogenous fertilizers in 1955 varied as follows: $\$ 6 \mathrm{r} .5^{\circ}$ per ton to Czechoslovakia; $\$ 92$ per ton to Rumania; $\$ 84.80$ per ton to Communist China; $\$ 90.3^{\circ}$ per ton to Hungary; $\$ 64.70$ per ton to Poland; and $\$ 6 \mathrm{r} .00$ per ton to Greece. ${ }^{10}$

\footnotetext{
14 See N.Y. Times, Sept. 28, 1958, p. 5, cols. $I$ and 2.

${ }^{15}$ See Mikesell \& BeHRMan, op. cit. supra note 12 , at $91-92$.

${ }^{26}$ See Economic Commission for EuRope, Economic Survey of Europe IN 1957, at 28 (1958).
} 
Bulgaria is reported to have offered essence of roses in the United States in $195^{\circ}$ at $\$ 80$ per $7 / 8$ of an ounce, while Russia's Amtorg is reported to have offered the same Bulgarian product for $\$ 67 .^{17}$ There are numerous reports of bloc countries reexporting commodities acquired under bilateral trade agreements with free-world countries at re-export prices lower than the import price. There is substantial evidence that Czechoslovakia has been re-exporting Egyptian cotton (for which premium prices had been paid) to West European markets, thereby reducing Egypt's direct sales for free currencies. ${ }^{18}$ Indonesia has complained about bloc re-exports to world markets of her rubber, although Indonesia was paid a ten per cent premium over the world-market price. ${ }^{19}$

Such deals do not necessarily indicate sales at a loss. The loss or profitability of the transaction can only be determined from a full analysis of the bilateral terms of trade. For example, Czechoslovakia can well afford to sell Egyptian cotton at ten per cent below the nominal price paid to Egypt, if the machinery and armaments sold to Egypt under the bilateral agreement were priced at twenty per cent above world levels.

\section{IV}

\section{Bloc Trade Relations with Less-Developed Countries}

Beginning in 1954, the Sino-Soviet bloc has placed considerable emphasis on expanding trade with the less-developed countries. These efforts have included negotiation of trade and payments agreements and the extension of credits and technical assistance. Between 1953 and 1957, exports of twenty-two countries in Latin America, the Far East, the Middle East, and Africa to the Sino-Soviet bloc rose from $\$ 437,000,000$ to $\$ 740,000,000$. Whereas at the end of 1953 , the Sino-Soviet-bloc countries had forty-nine trade and payments agreements with the less-developed countries, at the end of 1957 , there were nearly 150 . From 1954 to February $x$, I958, agreements calling for the extension of $\$ 1,900,000,000$ in grants and long-term credits to the less-developed countries had been negotiated by the Sino-Soviet bloc; approximately $\$ 400,000,000$ represented military assistance. However, only fifteen per cent of the nonmilitary credits had been utilized by the end of 1957 .

Bloc credits are nearly always extended in the form of commodities and technical services. They are frequently tied to specific projects, such as the building of a steel mill in Bhilai, India, the paving of a road in Kabul, Afghanistan, or the construction of a nuclear reactor in Cairo. In this respect, they are similar to the project loans of the Export-Import Bank and the World Bank. There are, however, important differences. Borrowers cannot obtain competitive bids for machinery and other supplies from individual firms, as is the case with Export-Import Bank and World Bank loans. Agreements are subject to bloc-government dictation in their imple-

${ }^{27}$ See Nicolas Spulber, The Economics of Communist Eastern Europe 436 (I957).

${ }^{18}$ See N.Y. Times, March 8, 1957, p. 2, col. 4; see also Robert L. AIIEN, Middle EAst Economic Relations with the Soviet Union, Eastern Europe, and Mainland China 22 (1958).

${ }^{20}$ See Mikesell \& Behrman, op. cit. supra note I2, at 88. 
mentation. This has the disadvantage that credits may suddenly be terminated or deliveries delayed for political reasons. Thus, deliveries under the Yugoslav credits from the Soviet Union have fluctuated with political relations between the two countries.

Another difference more appealing to the less-developed countries is that credit agreements frequently provide that amortization and interest payments are to be made in commodities, rather than in foreign exchange. Also, interest rates-usually $2 \frac{1}{2}$ per cent-are lower than those in the case of Export-Import Bank or World Bank loans. On the other hand, countries receiving bloc credits are often charged prices which are substantially higher than those charged for the same goods from the West.

Bloc countries have sought to attract less-developed countries into trade agreements with assurances of a larger market and fixed prices for primary commodities and with offers of assistance for economic development or defense. The instability of world-market prices for rubber, rice, cotton, and other raw materials has undoubtedly been a factor motivating less-developed countries to divert a portion of their exports from free-world markets into bilateral trade channels with the Sino-Soviet bloc. In cases where the free-world countries' bargaining power has been strong, there has undoubtedly been a short-term gain over selling in free markets. This is perhaps best exemplified by Ceylon's rubber-rice barter deals with Communist China after the imposition of the Western embargo on shipments of rubber to Communist China from most free-world sources. On the other hand, Indonesia and Burma have been disillusioned in their trade deals with Soviet-bloc countries.

Both political and economic motivations underlie the Sino-Soviet-bloc countries' trade and aid programs in the less-developed countries. Undoubtedly, they are seeking political advantage by becoming important importers of raw materials and dispensers of aid. Sometimes this economic power is used nakedly to topple proWestern governments-as they have succeeded recently in doing in Finland; or to influence a cabinet shift-as they have sought to do in Iceland; ${ }^{20}$ or to chastise-as was done when the Soviet Union canceled credits to Yugoslavia in 1948. More commonly, bloc economic power has been wielded much more subtly. For example, there have been numerous attempts to obtain the support of business and labor in Western countries for the negotiation of trade pacts and the elimination of strategic export controls. However, the greater the degree to which a country becomes dependent upon Soviet markets or on bloc economic assistance for fulfilling a develop-

${ }^{20}$ Beginning in August 1958 , the Soviet Union cut off certain imports from Finland and refused to participate in the annual trade talks scheduled for October, in an effort to embarrass Prime Minister August Fagerholm, who had refused to take Communists into his coalition government. The Prime Minister resigned early in December 1958, partly as a consequence of worsening economic conditions caused by the drop in exports to the Soviet Union. See N.Y. Times, Dec. 5, 1958, p. I, col. 7; p. 10, cols. 3 and 4. When Iceland had a Communist cabinet officer, the Soviet Union offered an agreement to purchase fish. When the Communist was ousted, the agreement was not renewed until a Communist once again became a member of the government. See MrKesenl \& BEHRMAN, op. cit. supra note I2, at 28. 
ment plan, the greater will be the power which the bloc can exercise for its political ends.

In addition to these political motivations, there are strong economic reasons why the bloc countries are anxious to expand their economic relations with primaryproducing countries. There is considerable evidence that costs in the extractive industries, including agriculture, have been rising in the Soviet Union relative to costs in manufacturing. The rapid industrialization over the past thirty years and the heavy allocations of capital for industry have tended to decrease the relative costs of finished manufactures and capital goods. Thus, there is some indication that the Soviet Union has a comparative advantage in exporting manufactures and importing primary goods from the less-developed countries. ${ }^{21}$ It is even possible to justify Soviet credit programs in terms of economic advantage in much the same way that United States and British foreign investments have provided a larger and cheaper source of raw materials from the less-developed countries.

For other members of the Sino-Soviet bloc, economic motivations for trade with the less-developed countries play perhaps an even more significant role. The countries of East Europe are dependent upon imports of raw materials for the fulfillment of economic plans; in the past, these have been very largely supplied by the Soviet Union. It would benefit East European countries to import primary products from other sources if they can be obtained on advantageous terms. This has the added advantage of making East European countries somewhat less dependent upon trade with the Soviet Union. To the extent that supplying the satellites with raw materials has been a burden to the Soviet Union, it, too, might welcome increased East European trade ties with the less-developed countries.

\section{$\mathrm{V}$}

\section{Obstacles to the Expansion of East-West Trade}

While the volume of trade among free-world countries has risen about seventy per cent over prewar levels, East-West trade is still well below the prewar volume. This is true in spite of a fifty per cent rise in trade between East and West Europe since 1953. A number of factors have contributed to the failure of East-West trade to expand in proportion to the general rise in world trade and production. These include: ( $\mathrm{x}$ ) the bilateral character of trade and payments; (2) the rigidities inherent in state-controlled trade; (3) the political tensions which have led to restrictions on exports of strategic materials to the Sino-Soviet bloc; and (4) Sino-Soviet policies of self-sufficiency and the political and economic isolation imposed by communist governments.

The Sino-Soviet variety of state trading greatly limits contacts between foreign buyers and sellers on the one hand, and the producers and distributors within the bloc countries on the other. Sino-Soviet countries, do, of course, have sales representatives

${ }^{21}$ See Joseph S. BerLINER, Soviet Economic AId II9-36 (1958); see also Allen, Economic Motives in Soviet Foreign Trade Policy, 25 So. Econ. J. 189 -(1958). 
in other countries as well as purchasing missions, but they are not an adequate substitute for direct contact between producers and consumers. This is remedied to some degree by the holding of trade fairs in both West and East European countries, where Western businessmen often have an opportunity to meet directly with officials of producing agencies.

The process of negotiating bilateral agreements which plan trade over a period of a year or more is also stifling to trade. These practices are not necessarily inherent in state ownership, since conceivably state enterprises could operate in international markets in much the same way as private corporations.

One of the most serious obstacles to East-West trade rises out of the payments arrangements provided in most trade agreements. While trade among nonbloc countries has become increasingly multilateral in character and is largely financed with transferable currencies, East-West trade remains largely bilateral and is financed through clearing accounts. This means that trade must be planned so as to achieve a bilateral balance. If trade becomes unbalanced so that surpluses accumulate in excess of the permitted swing credits, the creditor country stops exporting until the debit is settled either by goods or by alternative means.

While continuing to favor bilaterally negotiated trade, the Soviet Government has recognized the limitations of bilaterally balanced trade. It has cooperated in arrangements whereby surpluses with one trading partner could be used to settle a deficit balance with another, without the use of generally transferable currencies. For example, several triangular agreements were negotiated by the Soviet Union with Finland, with either Poland, Hungary, Czechoslovakia, East Germany, or Rumania as the third party. The agreements provided for a surplus of Finnish exports to the Soviet Union to be settled by an excess of Finnish imports over exports vis-d-vis the satellite countries; the Soviet surpluses with the satellite countries completed the circuits. Agreements were kept in rubles, and ruble accounts were transferred as trade progressed among the three participating countries. This system broke down in 1957 because of the refusal of the satellite countries to continue scheduled deliveries to Finland. Apparently, the cancellations were caused by satellite dissatisfaction with their own trade relations with the Soviet Union. This experience provides a clue to the inability of the Soviet Union to launch an intrabloc multilateral payments system based on the ruble. The value of the ruble in trade is a negotiated one; consequently, rubles transferred from third countries have a very uncertain value in terms of what they will buy from the Soviet Union. ${ }^{22}$

Many of the East-West trade and payments agreements provide for the transfer of bilateral clearing balances to third countries by mutual consent of all three parties; but in practice, few such transfers have been made. Some multilateral settlements have been achieved through re-exports to third countries. For example, Finland has re-exported to West Europe wheat imported from the Soviet Union in order to settle deficits in West European currencies.

${ }^{22}$ Sec MiKeSELI \& BEHRMAN, op. cit. silpra note 12, at 54-55. 
A. The ECE Clearing Scheme

After several years of negotiation, in June I957, the Economic Commission for Europe (ECE) instituted a procedure whereby at quarterly intervals, governments may inform the ECE Secretariat of claims and liabilities arising out of the operation of clearing accounts which they wish to submit for compensation. The Secretariat then makes specific proposals for offsetting these debit and credit balances. These proposals take the form of circuits linking a series of bilateral credits and deficits, so that for each country, cancellation of a debit is compensated by cancellation of an equivalent credit. The proposed circuits require the consent of all parties concerned. There is no obligation to disclose total financial positions vis-à-vis other countries, nor are balances merged into net debtor or creditor positions. Even when a country has submitted a credit balance for consideration, it may refuse to have the balance included in a circuit if the corresponding debit balance which it would compensate is not acceptable.

As of July $195^{8}$, there had been five quarterly compensations with arrangement for the cancellation of balances, with a total value equivalent to $\$ 37,000,000 .^{23}$ Bulgaria, Czechoslovakia, Denmark, Finland, France, Greece, Hungary, Israel, the Netherlands, Norway, Poland, Rumania, Sweden, Switzerland, Uruguay, the Soviet Union, East Germany, and Yugoslavia have been participants in the circuits. Through April 1958, a total of $\$ 182,000,000$ in credit balances were reported to the ECE Secretariat for compensation. Over half of these, $\$ 97,000,000$, could not be compensated because the country against which the balance was held refused the proposed compensation.

Compensations have been only a small proportion of trade between East and West Europe. Total trade turnover in 1957 was more than $\$ 3,300,000,000 .^{24}$ Compensations for the first year of operations were less than one per cent of the trade turnover between the two areas in I957. Of course, compensations can have a stimulating effect on trade out of proportion to their volume if they succeed in bringing balances within the limits of the swing credits stipulated in the payments agreements. But the volume and effectiveness of compensations under the present ECE clearing agreement are likely to remain at a relatively low level. Some of the reasons for this conclusion, as indicated in the following paragraphs, are inherent in the nature of bloc trading practices:

I. It is difficult to suggest clearing circuits to which all members will agree. Moreover, some of the most important West European countries, including Britain, West Germany, and Belgium, have refused to participate in the arrangements.

2. There are substantial differences in the real purchasing power of balances with the same nominal value, but which are denominated in different currencies.

\footnotetext{
${ }^{23}$ See Economic Commission for Europe, Agents' First Annual Report on the Operation of the Multilateral Conpensation Procedures Organized Under the Auspices of the United Nations EcoNOMIC COMMISSION FOR EUROPE 4 (1958).

24 io Econ. Bull. For Europe 60-6i (1958).
} 
In general, a balance with an EPU country may be used to acquire a larger variety of goods than a similar one with a bloc country. Moreover, EPU currencies can be exchanged for EPU credits which are partially settled in gold, or the EPU currency can often be sold in free markets for dollars at a small discount. For these reasons, a balance with a bloc country is not likely to be equated with a balance in a Western currency. The operations of the clearing agreement confirm this. During ECE operations covering the period from June 1957 to September 1957 , there were no circuits compensated in which an EPU country canceled a claim on another EPU country in exchange for a cancellation of a debit balance with a bloc country. Similarly, a bloc country would not ordinarily be interested in losing a credit balance against an EPU country in settlement of a debt which it owed to another bloc country. In any circuit involving two bloc countries or two EPU countries, it has usually been necessary for a country which is neither an EPU member nor a bloc country to act as an intermediary (e.g., Finland, Israel, Yugoslavia, or Uruguay).

3. Even if all participating countries agreed to submit all their balances for automatic clearing each period, the offset-clearing arrangements employed by the ECE Secretariat are incapable of full multilateral clearing such as is provided by the EPU or by the financing of trade with convertible currencies.

4. Finally, the ECE clearing mechanism does not remove the underlying bilateral basis for East-West trade. Trade is still planned to achieve bilateral balance; the clearing mechanism operates principally to compensate unplanned surpluses or deficits. But planned multilateral trade involving East-West partners, even if there were a mechanism for its implementation, would be extremely difficult to achieve. Moreover, it would probably be opposed by bloc countries because it would tend to reduce their bargaining power vis-à-vis individual Western countries.

The absence of a multilateral clearing system among the Sino-Soviet-bloc countries themselves has been a barrier to the clearing of East-West balances. At the June I957 session of the CEMA, it was announced that agreement had been reached for the creation of a multilateral trade and clearing system for members, including Albania, Bulgaria, Czechoslovakia, East Germany, Hungary, Poland, and the Soviet Union. While no details on the operation of this system have been announced, a report of a June $195^{8}$ meeting of the board of directors of the banking systems of twelve communist countries stated that Bulgaria had proposed that all trade of the communist countries be made subject to the multilateral clearing system which was initiated about a month prior to the meeting. ${ }^{25}$ This announcement implies that operations have just begun and that only some trade balances are submitted for clearing. At this same meeting, a proposal calling for the establishment of an interna-

${ }^{25}$ See N.Y. Times, Aug. I9, 1958, p. 4, col. I. 
tional bank for communist-bloc countries was not adopted, and the press accounts implied that the Soviet Union was not one of its sponsors and had not supported it.

VI

IMPLications For Western Policy

We are now ready to deal more specifically with the three questions raised in our introduction.

\section{A. Influence of Sino-Soviet-Bloc Trading Practices on State Trading in the Free World}

The vast bulk of the world's trade among countries outside the Sino-Soviet bloc is conducted on a multilateral basis and financed with transferable currencies. On the other hand, seventy per cent or more of free-world trade with the bloc is conducted under bilateral agreements. To a very large degree, trade with bloc countries is on a government-negotiated basis, largely because of the insistence, or of special inducements, by the bloc trading partners. However, some nonbloc countries whose trade with the rest of the world is on a multilateral basis prefer to conduct their trade with the bloc on a negotiated basis.

Bilaterally negotiated trade financed through clearing accounts tends to promote or perpetuate state trading on the part of the free-world partners. It is easy to see why this is true. Barter deals such as the rubber-rice agreements between Ceylon and Communist China and the cotton-wheat barter deals between Egypt and the Soviet Union are nearly impossible to consummate except on a governmentto-government basis. Even aside from barter deals, trade agreement targets are usually difficult to meet when trade is on a private voluntary basis. If imports fall below agreed levels, the free-world country accumulates an inconvertible balance and becomes an involuntary creditor. On the other hand, if exports fall short of agreement levels, a deficit may be accumulated for which settlement in foreign exchange or in commodities that can readily be sold for foreign exchange on world markets is demanded. Also, unless prices of exports and imports are supervised carefully, the terms of trade of the free-world country will suffer. Private concerns may feel that they are bargaining at a disadvantage with bloc trade monopolies, and in some cases, free-world governments have assisted in the formation of semiofficial trade associations for dealing with bloc countries. There is also the problem of policing shipments of strategic materials in line with Western control agreements. Still another factor making for state trading has been the long-term credits extended by bloc countries to the less-developed countries. These credits, of course, are made to governments rather than to private firms. Finally, Western nations may fear that their economies may become too dependent upon orders from bloc countries and that this dependence will be used to gain political advantage by the bloc countries. They may seek to avoid this by insisting that trade with the bloc be on a government-to-government basis. 
In 1956, India, whose trade with bloc nations has been expanding, established a state-trading agency to monopolize trade with the bloc. State trading even applies to consumer goods, which is normally in private hands in India. All of Ceylon's trade with Communist China is in government hands, and Egypt's deals with bloc countries have been responsible for the nationalization of much of Egypt's foreign trade.

B. Implications for Free-World Policies in Trading with the Sino-Soviet Bloc

The fundamental principle which must be recognized in all economic dealings with bloc countries is that economics is a political weapon. The idea of foreign trade and investment for mutual economic gain conducted within a framework of political neutrality is foreign to communist ideology. Trade and credit agreements will be denounced or modified whenever this seems advantageous from a political standpoint.

This does not mean that free-world countries should not trade with the bloc or that their own private trade with bloc countries should be eliminated in favor of state trading. Free governments would be well advised, however, to trade on a commercial basis, without negotiating trade agreements or accepting clearing-account credits. This means that trade with the bloc countries should be in private hands except where, for one reason or another, countries have created a state-trading monopoly for all foreign trade in a particular commodity. If bloc countries are required to pay convertible currencies for the goods that they buy and to compete in free international markets in order to sell abroad, there is little danger that private traders will be at a serious disadvantage in trading with bloc countries.

A case can be made for special government controls on private trade with the bloc, however. Sporadic "dumping" of commodities by bloc countries which may have the effect of disrupting production in free-world economies should be prevented. In the case of primary commodities, international action on the part of free-world countries may need to be employed in order to avoid harmful effects of large and sudden bloc exports on primary-producing countries. ${ }^{20}$ It should be said, however, that dumping, which is defined as selling in foreign markets at prices lower than those prevailing in the domestic market for similar quantities, is virtually impossible to prove in the case of bloc countries. This is true because of a lack of any real basis for comparing internal bloc prices with prices charged in external transactions.

A case for government controls can be made also for preventing private exporters in free-world countries from becoming too dependent upon bloc markets, especially through long-term contracts. Such controls would be scarcely justified for larger

\footnotetext{
${ }^{28}$ In September 1958 , the Soviet Union was accused by representatives of Bolivia, Malaya, and other tin-producing countries of disrupting the world market for tin by dumping. Soviet exports of tin rose from 450 tons in 1956 to 9,000 tons in 1957 and were reported to be running at double the I957 rate during the summer of 1958. See N.Y. Times, Oct. 3, 1958, p. 4r, cols. 2 and 3; p. 44, cols. 2, 3, 4.
} 
trading countries such as the United States, Britain, and West Germany, but they might well be regarded as essential to the economic security of a country like Austria.

\section{Intergovernmental Cooperation on East-West Trade Problems}

Much has been written about the desirability of reducing international tensions through trade and other forms of international economic cooperation between freeworld and bloc countries. There is perhaps something to be said for this position. Trade promotes broader contacts between residents on either side of the Iron Curtain and helps to dispel gross misconceptions, in spite of efforts of governments to perpetuate them. On the other hand, the basis for useful trade cooperation through intergovernmental agreement is extremely narrow for two principal reasons: (I) codes of international fair trade practices, such as are embodied in the General Agreement on Tariffs and Trade, are almost completely devoid of significance when applied to Sino-Soviet-bloc countries; and (2) the types of agreements sought by the bloc countries are either of questionable value or are clearly harmful for free-world countries to undertake.

When the International Trade Organization charter was drafted in I948, an effort was made to embody provisions relating to such matters as most-favored-nation treatment, import controls, tariffs, and dumping which would be appropriate to countries with state-trading enterprises as well as to private-enterprise economies. ${ }^{27}$ Certain of these provisions were also embodied in the General Agreement on Tariffs: and Trade (see article seventeen). While it is conceivable that a country whose foreign trade was entirely in the hands of state-trading enterprises might in good faith follow these principles, it is clear that they are without meaning for the internal and external trading systems of bloc countries. The reasons may be summarized as. follows:

I. Tariffs, import restrictions, or export subsidies have no significance in countries whose internal trade is completely controlled by the state and where the internal price structure has little or no relation to world prices.

2. Most-favored-nation or commercial-consideration clauses have no significance for countries whose trade is organized on the basis of bilateral trade negotiations, bilaterally negotiated prices, and of financing through clearing accounts. Such practices are the very antithesis of the principle of nondiscrimination in trade. ${ }^{28}$

3. Fair-commercial-practices codes have no significance whatsoever for countries employing trade as a political weapon.

${ }^{27}$ See Havana Charter for an International Trade Organization c. 4, \$ D, arts. 29-32 (Dept. of State Pub. No. 3206, 1948).

${ }^{28}$ Sec, e.g., Domke \& Hazard, State Trading and the Most-Favored-Nation Clause, 52 AM. J. INr's. L. 55 (1958). 
All this is not to say that international agreements could not be negotiated on such matters as uniform commercial documents, marks of origin, and other formalities concerned with importation and exportation or on international arbitration of certain types of disputes arising out of commercial contracts. It is even possible for bloc countries to become parties to international commodity agreements involving export or import quotas.

The degree of participation by the communist countries in the work of the ECE is instructive. As might be expected, it has closely followed political trends. The annual meetings of the Commission have been generally little more than cold war propaganda forums. The real work of the ECE has been done in the specialized committees which correspond to fields such as coal, steel, timber, inland transport, agriculture, and trade. The committee work is done in complete privacy, with the aid of an independent and aggressive Secretariat. Trade consultations under the auspices of the ECE in April I953 were instrumental in helping to raise the volume of East-West trade from the low levels of preceding years. However, in all cases, Eastern countries have not relinquished their absolute independence in the field of trade nor have they accepted procedures which might alter their trading practices.

What types of international agreements or arrangements are currently sought by the Sino-Soviet bloc? In general, bloc countries favor agreements with free-world countries which promote bilaterally negotiated trade and credit arrangements. Such agreements enhance their economic and political bargaining power in dealing with individual free-world nations. They dislike free international markets and internationalized loans, foreign aid, and technical assistance provided by the United Nations or specialized agencies such as the World Bank.

The Soviet Union and the European satellites are cooperating in the ECE clearing scheme not because they want to replace bilateralism with multilateral trade and payments, but because offset clearings can be employed at their own discretion, to facilitate the operation of bilateral trade and payments agreements. The scheme also adds respectability to bilateral trade agreements by making them appear more multilateral than they really are. For this reason, the writers believe that Britain, West Germany, and Belgium were entirely correct in opposing the inauguration of the clearing scheme by the ECE Secretariat. As a counterproposal, the British suggested that East-West trade be financed with EPU currencies and that payments arising out of trade with the Soviet bloc be made freely transferable within the EPU area (as is already the case with sterling and Deutsche mark).

\section{Conclusions}

Trading practices and policies of Sino-Soviet-bloc countries present a threat to orderly world trading not because they involve state trading as such, but because bloc countries insist, whenever possible, upon bilateralism and employ trade as a political weapon. Bilateralism is inherently discriminatory, and the lack of any consistent relationship between costs and selling prices within bloc countries' on the 
one hand, and world-market prices on the other, makes trade in accordance with commercial considerations virtually impossible. Codes of international fair trade practices have no significance for bloc countries; international agreements concerned with tariffs, import quotas, subsidies, and dumping are meaningless.

Most countries of the free world have adopted bilateralism and state-trading practices in their trade with countries of the Sino-Soviet bloc. In some cases, they have been forced to adopt these practices as a condition for obtaining export markets and credits from the bloc. In other cases, free-world countries have adopted trade and payments controls as a means of improving their bargaining position vis-à-vis the bloc countries and of protecting themselves against arbitrary trading practices by their bloc partners.

Experience has shown that bilateral trade with the bloc provides neither trade stability nor better terms of trade as compared with trade in free international markets. Moreover, it is our view that free-world countries cannot protect themselves against harmful consequences of trading with the bloc by negotiating bilateral agreements or by organizing state-trading agencies. Such policies play into the hands of the communists by making trade with bloc countries directly subject to political pressures. If all free-world countries adhered to the rules of the General Agreement on Tariffs and Trade and of the International Monetary Fund with respect to bilateral trade and payments practices, it would be easier for countries to reject bloc insistence on bilateral deals as a condition for trade. Moreover, if all free-world countries abandoned bilateralism, bloc countries would be required to buy and sell on the basis of competitive bidding in free international markets. Trade would be conducted on the basis of commercial considerations.

If bilateralism were abandoned by the free world as a means of trading with the bloc, free-world organizations should be authorized to protect countries from severe economic pressures from the bloc and to assist victims of bloc economic aggression. For example, the International Monetary Fund or the World Bank might provide special assistance to countries whose exports to the bloc were suddenly terminated. Similarly, members of the International Tin Agreement might establish emergency quotas on excessive Soviet exports of tin in order to protect tin-producing countries from bloc dumping practices. In these and other ways, members of the free-world community should seek cooperative measures for defending weaker members against economic aggression by the Sino-Soviet bloc.

$$
\text { **** }
$$

Note: Since this article was written, the EPU was discontinued (end of December $195^{8}$ ) and the major West European currencies have become convertible for nonresident holders. The implications of this development for trade with the Sino-Soviet bloc were not available at this writing. However, it is likely to mean a further weakening, if not the elimination, of bilateral payments arrangements between West European countries and the Sino-Soviet bloc. 